Original Research Paper

\title{
Effect of Heat Stress on the Expression of HSP70, UCP3 and CYP450 Genes in Liver; Longissimus Dorsi and Semitendinosus Muscle of Growing Pigs
}

\author{
${ }^{1,2}$ Montesinos-Cruz, V., ${ }^{1}$ M. Cota, ${ }^{1}$ L. Buenabad, ${ }^{1}$ M. Cervantes and ${ }^{1}$ A. Morales \\ ${ }^{1}$ Instituto de Ciencias Agrícolas, Universidad Autónoma de Baja California, Mexicali 21100, México \\ ${ }^{2}$ Departamento de Toxicología, CINVESTAV Instituto Politécnico Nacional, Ciudad de México 07360, México
}

\author{
Article history \\ Received: 01-08-2019 \\ Revised:16-09-2019 \\ Accepted: 16-10-2019 \\ Corresponding Author: \\ Adriana Morales Trejo \\ Instituto de Ciencias Agrícolas, \\ Universidad Autónoma de Baja \\ California, Mexicali 21100, \\ México \\ Tel. +526865230088 \\ Email: adriana_morales@uabc.edu.mx
}

\begin{abstract}
High Ambient Temperature (AT) provokes Heat Stress (HS) in animals, which is characterized by increased body temperature, Reactive Oxygen Species (ROS) production and cell damage. Uncoupling Proteins (UCP) may contribute to dissipate body heat, cytochrome P450 (CYP3A4) reduces ROS and Heat Shock Proteins (HSP) prevent protein denaturalization. This study analyzed the expression of HSP70, UCP3 and CYP3A in liver, Longissimus Dorsi (LD) and Semitendinosus (ST) muscles of pigs exposed to HS conditions. A 21-d experiment was conducted with 18 pigs $(32.6 \pm 3.2 \mathrm{~kg}$ body weight) divided into 3 treatments: (1) HS, pigs exposed to natural AT $\left(29.5-37.2^{\circ} \mathrm{C}\right)$ fed $a d$ libitum; (2) TNad, thermoneutral conditions $\left(24.0 \pm 2.0^{\circ} \mathrm{C}\right)$ fed ad libitum; (3) TNpf, thermoneutral fed same amount as HS pigs. Hepatic expression of HSP70 in HS pigs was 4-fold higher than in TNad pigs ( $\mathrm{p}=0.039$ ); no differences were observed between HS and TNpf, or between TNad and TNpf pigs ( $>0.10)$. There were no differences in HSP70 expression in both muscles ( $p>0.10$ ) because of HS or feed intake. Expression of UCP3 in $L D$ and ST did not differ ( $p>0.10$ ) between treatments; neither the expression of CYP3A in liver was affected by HS, or feed intake level ( $\mathrm{p}>0.10)$. Apparently, pigs became adapted to HS because expression of mitochondrial UCP3 and CYP3A was not affected after $21 \mathrm{~d}$ of HS exposure and the increased HSP70 expression in liver could have helped cells to maintain their proteins integrity.
\end{abstract}

Keywords: Heat Stress, Heat Shock Protein, Uncoupling Protein, CYP3A, Pig

\section{Introduction}

Heat Stress (HS) occurs when Ambient Temperature (AT) and relative humidity exceed the Thermo Neutral (TN) zone of organisms leading to a series of physiological and behavioral responses. Heat stress pigs increase their respiratory frequency and heart rate to dissipate more body heat (Wilson and Crandall, 2011) and consume less feed to decrease body heat production (Bernabucci et al., 2010). Nonetheless, pigs exposed to severe HS increase Body Temperature (BT) up to $2.0^{\circ} \mathrm{C}$ (Pearce et al., 2013; Morales et al., 2016), which might result in cell death (Rhoads et al., 2013).

Body heat receptors appear to sense temperature changes at cellular level to maintain BT balance and prevent cell death. Heat Shock Proteins (HSP) are inducible proteins that prevent protein denaturalization under high AT (Katschinski, 2004). HSP70 is highly conserved in cells (Bakau and Horwich, 1998), whose expression is associated with a thermo tolerance cellular response (Kregel, 2002) and the presence of Reactive Oxygen Species (ROS) (Kregel, 2002). HS increases ROS production in mitochondria (Mujahid et al., 2007). Uncoupling Proteins (UCP) are mitochondrial anioncarriers that generate heat by dissipating the mitochondrial proton gradient, uncoupling respiration from ATP synthesis (Palmieri, 1994). UCP2 and UCP3 also attenuate the mitochondrial ROS production and protect against ROS-induced cellular damage (Mookerjee et al., 2010). The cytochrome P450s (CYPs) are proteins responsible for drugs metabolism (Duester, 1996), although it has been observed also that mouse 
hepatocytes increase expression of the P450 isoform CYP3A4 under HS conditions (Li et al., 2012). Although these studies were conducted under highly controlled artificial lab conditions, we hypothesize that pigs exposed to natural HS conditions and different feed intake level will differently express genes coding for those proteins.

The objective of this study was to analyze the expression of HSP70, UCP3 and CYP3A in liver, Longissimus Dorsi (LD) and Semitendinosus (ST) muscle of pigs exposed to TN or natural HS conditions and different feed intake level.

\section{Materials and Methods}

\section{Animals, Housing and Diets}

All pigs in this experiment were cared for in accordance with the guidelines established in the Official Mexican Regulations on Animal Care (NOM-062-ZOO1999, 2001). The study was conducted in Northwestern Mexico during summer time when AT fluctuates every day from 25 to $42^{\circ} \mathrm{C}$. Eighteen crossbred (Landrace $\mathrm{x}$ Hampshire $\mathrm{x}$ Duroc) pigs with an initial body weight of $32.6 \pm 3.2 \mathrm{~kg}$ were randomly assigned to one of three treatments based on sex ( 3 males and 3 females), litter and body weight. Treatments were: HS, pigs exposed to high natural ambient temperature (housed in a room with no temperature control) and fed ad libitum; TNad, pigs exposed to thermo-neutral conditions (housed inside an air-conditioned room with the thermostat set at $24 \pm 2{ }^{\circ} \mathrm{C}$ ) and fed ad libitum; TNpf, thermo-neutral pigs pair-fed with the HS pigs. There were six replicates per treatment. All pigs were individually housed in raised floor metabolism pens $(1.2 \mathrm{~m}$ wide, $1.2 \mathrm{~m}$ long and $1.0 \mathrm{~m}$ high) equipped with a stainlesssteel self-feeder, a nipple water drinker and iron mesh floor. Ambient temperature inside each room was recorded every $15 \mathrm{~min}$ during the study with the aid of a Higrothermograph (Thermotracker HIGRO; iButtonLink LLC, Whitewater, WI, USA).

All pigs were fed the same diet based on wheat $(905 \mathrm{~g} / \mathrm{kg})$ and soybean meal $(65 \mathrm{~g} / \mathrm{kg})$ supplemented with $0.48 \%$ L-Lys and $0.13 \%$ L-Thr, vitamins and minerals, which met the NRC (2012) requirements for pigs within the body weight range of 25 to $50 \mathrm{~kg}$. The diet contained $14.0 \% \mathrm{CP}$ and $10.1 \mathrm{MJ}$ of $\mathrm{NE}$ per $\mathrm{kg}$. The feed intake of HS pigs was restricted to $95 \%$ of their ad libitum feed intake recorded the previous week, which was approximately $20 \%$ lower than the voluntary feed intake of TNad pigs. This amount of feed was adjusted every week during the study. The TNpf pigs were pair-fed with HS pigs; these pigs were fed two times a day at 0700 and $1900 \mathrm{~h}$ in two equal meals. All pigs were adapted to the metabolism pens and trained to consume their daily meals within 30 min or less, during 7 days before the trial started. Purified water was available to all pigs during the study. The experiment lasted $21 \mathrm{~d}$; the average body weight of pigs at the end of the study was 44.2, 49.2 and $43.6 \mathrm{~kg}$ for HS, TNad and TNpf, respectively.

\section{Collection of Tissue Samples}

At the end of the experiment, all pigs were sacrificed by electrical stunning and exsanguination. Immediately after slaughter, samples (0.5 g) of liver, Longissimus Dorsi (LD) and Semitendinosus (ST) muscles were collected into $2 \mathrm{ml}$ micro tubes. Also, samples of blood and intestinal epithelia were collected to analyse the expression of amino acid transporters in the small intestine and the concentration of free AA in serum; these data are already published (Morales et al., 2016). All samples were immediately frozen in liquid nitrogen and stored at $-80^{\circ} \mathrm{C}$ until lab analysis.

\section{Total RNA Extraction and Purification}

All tissue samples were treated to extract total RNA by the Trizol reagent (Invitrogen, Corp., Carlsbad, CA, USA), as reported previously (Méndez et al., 2011). Purified RNA was then eluted with RNase-free water and stored at $-80^{\circ} \mathrm{C}$. The integrity of total RNA was evaluated by gel electrophoresis on $1 \%$ agarose gels. All RNA samples had good quality with a $28 \mathrm{~S}: 18 \mathrm{~S}$ rRNA ratio around 2.0: 1 (Sambrook and Russell, 2001). The concentration of total RNA was determined spectrophotometrically at $260 \mathrm{~nm}$ (Helios $\beta$, Thermo Electron Co., Rochester, NY, USA) and purity of RNA was assessed by using the A260/A280 ratio, which ranged from 1.8 to 2.0 (Sambrook and Russell, 2001). Approximately $2 \mu \mathrm{g}$ of total RNA were treated with $1 \mathrm{U}$ of DNase I ( $1 \mathrm{U} \mu \mathrm{L}^{-1}$; Invitrogen) and reverse transcription was performed using random hexamers as previously described (García et al., 2015). The complementary DNA samples were quantified and diluted into a final concentration of $50 \mathrm{ng} / \mu \mathrm{l}$.

\section{Quantitative PCR ( $q P C R)$}

Specific primers for HSP70, UCP3 and CYP3A mRNA and 18S rRNA gene were designed according to their published sequences at the GenBank (Table 1). End point PCR were carried out to standardize the amplification conditions for each pair of primers and in order to confirm the specificity of the PCR products related to its mRNA, a sample of each PCR product was purified and sequenced at the GENEWIZ (South Plainfield, NJ, USA). Sequencing results revealed that the products for HSP70, UCP3, CYP3A and 18S rRNA showed $100 \%$ homology with their corresponding expected sequences acquired from the virtual template sequences reported in GenBank. 
Table 1: Primers used for the quantitative PCR analyses of messenger RNA derived from uncoupled protein (UCP3), heat shock protein 70 (HSP70), cytochrome P450 (P450) and 18S ribosomal RNA from pig

\begin{tabular}{|c|c|c|c|c|}
\hline mRNA & Primer & $\begin{array}{l}\text { Location (bp) } \\
\text { on the template }\end{array}$ & Sequence & Amplicon (bp) \\
\hline \multicolumn{5}{|c|}{ Sus scrofa heat shock protein 70 (HSP70), mRNA (GenBank: NM_001123127.1) } \\
\hline & $\begin{array}{l}\text { Forward } \\
\text { Reverse }\end{array}$ & $\begin{array}{l}289-307 \\
440-423\end{array}$ & $\begin{array}{l}\text { GCCCTGAATCCGCAGAATA } \\
\text { TCCCCACGGTAGGAAACG }\end{array}$ & 152 \\
\hline
\end{tabular}

Sus scrofa uncoupling protein 3 (UCP3) mRNA, nuclear gene encoding

mitochondrial protein, complete cds. (GenBank: AF128837.1)

$\begin{array}{lll}\text { Forward } & 820-839 & \text { GAACTGTGCCGAGATGGTGA } \\ \text { Reverse } & 1100-1081 & \text { AGCTTCCCAAGCGCAAAAAG }\end{array}$

Sus scrofa cytochrome P450 3A (CYP3A) mRNA, complete cds. (GenBank: AF424780.1)

Forward 1185-1204

GGTGCCAGTCTTCGTGCTTC

Reverse 1472-1451

Sus scrofa 18s ribosomal RNA complete sequence (GenBank: AY265350)

Forward 236-255

AGAACGACAGGTTTTTCCGTTG

The expression of mRNA codding for HSP70, UCP3 and CYP3A was analyzed by quantitative PCR (qPCR) assays and 18S rRNA gene was used as an endogenous control to normalize variations in mRNA expression. Expression of HSP70, UCP3 and CYP3A was analyzed in the LD and ST muscles and in liver. PCR reactions were performed by duplicate using the Maxima SYBR Green-ROX qPCR Master Mix 2X (Fermentas, Inc. USA) into a CFX96 Real-Time System (Bio-Rad, Herefordshire, England) and results were analyzed with the software CFX Manager 3.0 (Bio-Rad). Reactions for qPCR contained $50 \mathrm{ng}$ of cDNA, $0.5 \mu \mathrm{M}$ of each specific primer, $12.5 \mu \mathrm{L}$ of $2 \times$ SYBR green/ROX qPCR Master Mix and nuclease-free water to complete a final volume of $25 \mu \mathrm{L}$. PCR conditions used for the amplification and quantification were an initial denaturing stage of $95^{\circ} \mathrm{C}$ for $5 \mathrm{~min}$, followed by 40 cycles of amplification (denaturing at $95^{\circ} \mathrm{C}$ for $30 \mathrm{~s}$, annealing at $56^{\circ} \mathrm{C}$ for $30 \mathrm{~s}$ and extension at $72^{\circ} \mathrm{C}$ for $45 \mathrm{~s}$ ) and a melting curve program $\left(60\right.$ to $\left.90^{\circ} \mathrm{C}\right)$. Fluorescence was measured at the end of every cycle and every $0.2^{\circ} \mathrm{C}$ during the melting program. Three-replicate negative controls were used: qPCR reactions without DNA template; qPCR reactions with DNA template but no SYBR Mix; and qPCR reactions with DNA template but no primers. The melting curve of each specific qPCR product was analyzed to make sure that no primer dimers or nonspecific DNA products were quantitated. Results of quantitation of mRNA expression were analyzed according to comparative $\mathrm{Ct}$ method, expressed as $2^{-\Delta \Delta \mathrm{Ct}}$ (Livak and Schmittgen, 2001) and normalized by $18 \mathrm{~S}$ ribosomal RNA expression in each sample.

\section{Statistical Analysis}

Expression of mRNA for HSP70, UCP3 and CYP3A was analyzed using SAS (Statistical Analysis System 9.1; SAS Institute, Cary, NC, USA), according to a completely randomized design. Three contrasts were constructed to test the effects of exposing pigs to different ambient temperature at similar feed intake $\left(C_{1}\right.$,
HS vs. TNpf ), different feed intake under TN conditions $\left(\mathrm{C}_{2}, \mathrm{TNad} v s . \mathrm{TNpf}\right)$ and different ambient temperature and feed intake $\left(\mathrm{C}_{3}\right.$, HS vs. TNad). Probability levels of $\mathrm{p}<0.05$ and $0.05 \leq \mathrm{p}<0.10$ were defined as significant and tendencies respectively.

\section{Results}

\section{Feed Intake and Ambient Temperature}

Feed intake, as designed in the present experiment, did not differ between the HS and TNpf pigs $(1.2 \mathrm{~kg} / \mathrm{d})$. However, as expected, the TNad pigs consumed more feed $(1.47 \mathrm{~kg} / \mathrm{d})$ than the other two groups of pigs $(\mathrm{p}<0.05)$. Ambient temperature inside the room with no air-conditioning fluctuated every day from $29.5^{\circ} \mathrm{C}$ (around $0630 \mathrm{~h}$ ) to $37.2^{\circ} \mathrm{C}$ (around $1630 \mathrm{~h}$ ); the average temperature was $33.1 \pm 2.6^{\circ} \mathrm{C}$ (Fig. 1). In contrast, AT inside the air-conditioned room fluctuated from 24.0 to $28.1^{\circ} \mathrm{C}$, with an average of $25.9 \pm 1.4^{\circ} \mathrm{C}$.

\section{mRNA Expression}

The relative expression of mRNA coding for HSP70 in response to the exposure of pigs to different AT and feed intake level, varied depending on the analyzed tissue (Fig. 2). In liver, the expression of HSP70 was higher in pigs exposed to HS than in pigs exposed to TN conditions and fed ad libitum ( $\mathrm{p}=0.039$ ). However, no difference in HSP70 expression was observed between HS pigs and TN pigs having similar feed intake ( $\mathrm{p}=0.543)$, or between TN pigs fed either $a d$ libitum or restricted $(\mathrm{p}=0.110)$. Regarding the relative expression of HSP70 in muscle, no effect of ambient temperature at similar feed intake (HS vs. TNpf) was observed in LD $(p=0.528)$ and ST $(p=0.676)$, or feed intake level in pigs exposed to TN conditions (TNad $v s$. TNpf) in LD ( $\mathrm{p}=0.588)$ and ST $(\mathrm{p}=0.936)$. The HSP70 expression in the LD $(p=0.927)$ and ST $(p=0.732)$ muscles of HS pigs did not differ from that of TN pigs fed ad libitum (HS vs. TNad). 


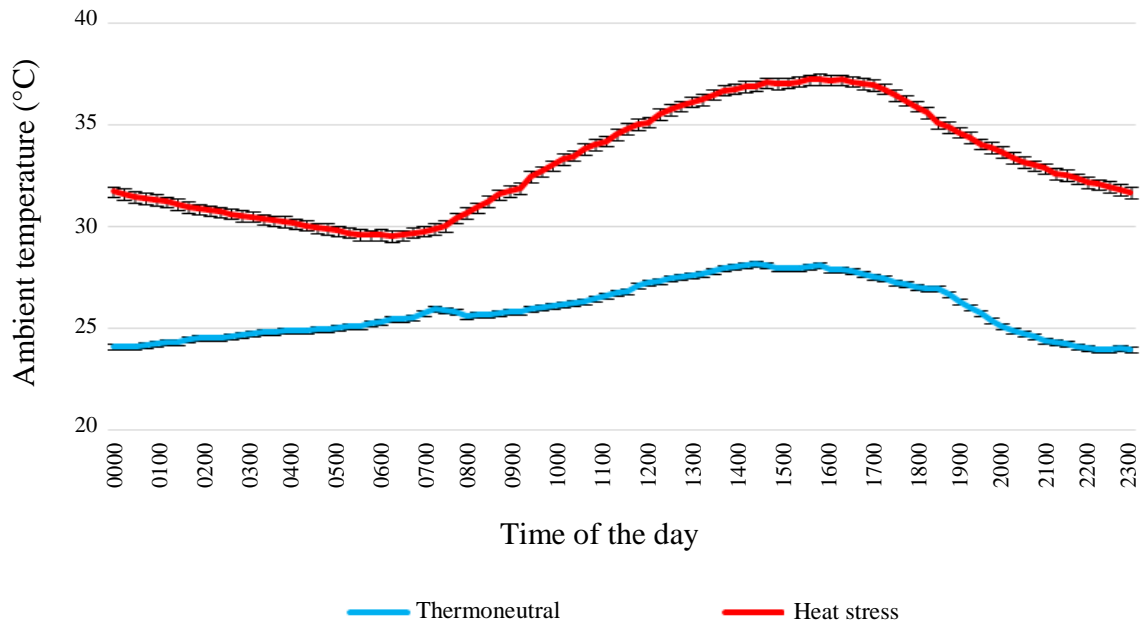

Fig. 1: Average ambient temperature inside the thermoneutral or heat stress room recorded at 15-min intervals

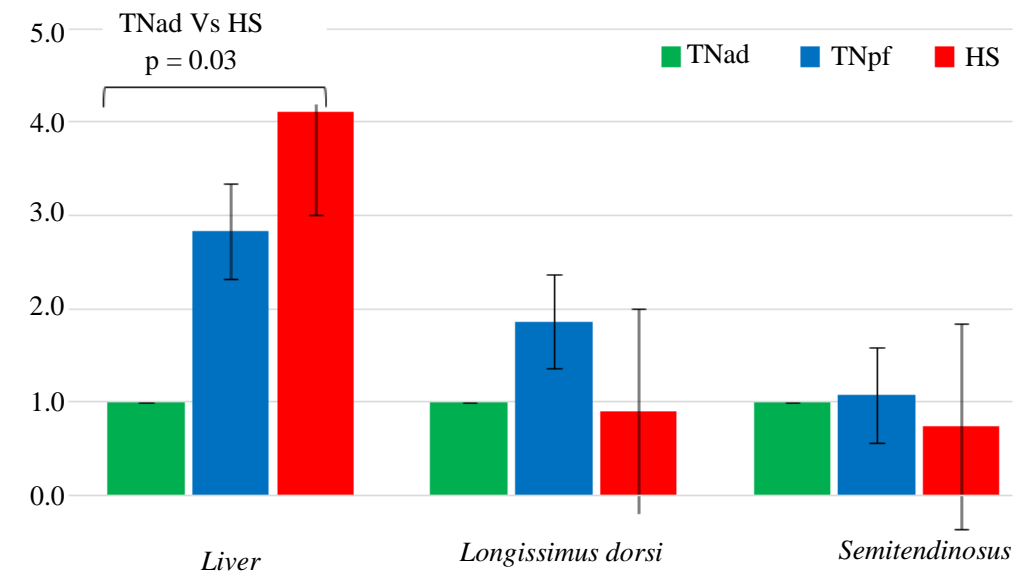

$-1.0$

Fig. 2: Fold of increase-decrease on expression of mRNA for HSP70 analyzed in liver and Longissimus dorsi and Semitendinosus muscles of pigs under thermoneutral ad libitum (TNad), thermoneutral pair fed (TNpf) or heat stress (HS) conditions

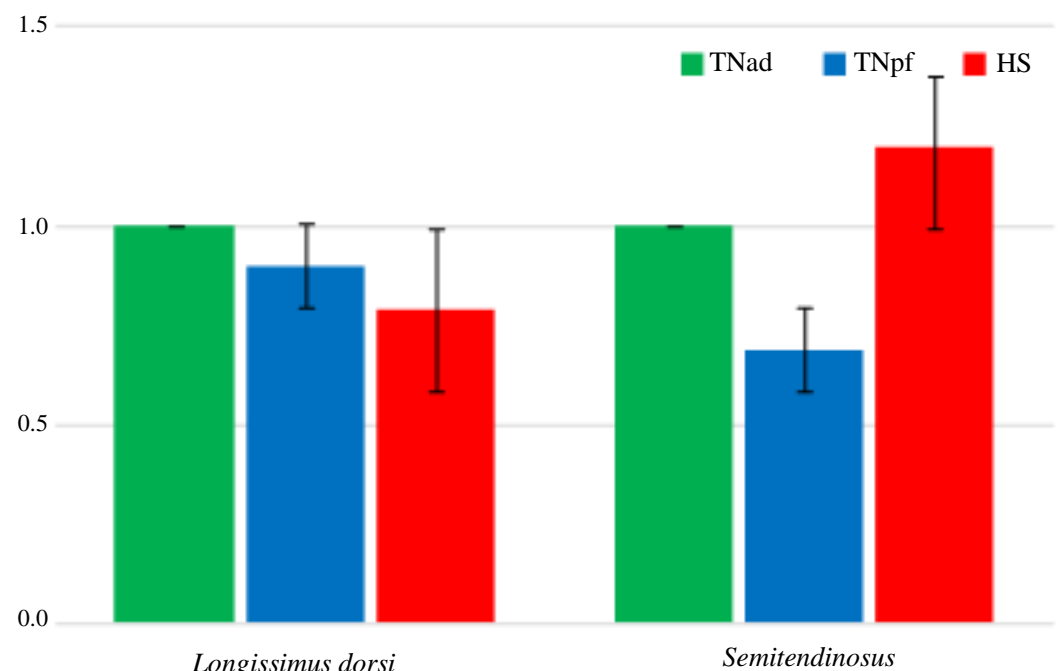

Fig. 3: Fold of increase-decrease on expression of mRNA for UCP3 analyzed in longissimus dorsi and semitendinosus muscles of pigs under thermoneutral ad libitum (TNad), thermoneutral pair fed (TNpf) or heat stress (HS) conditions 


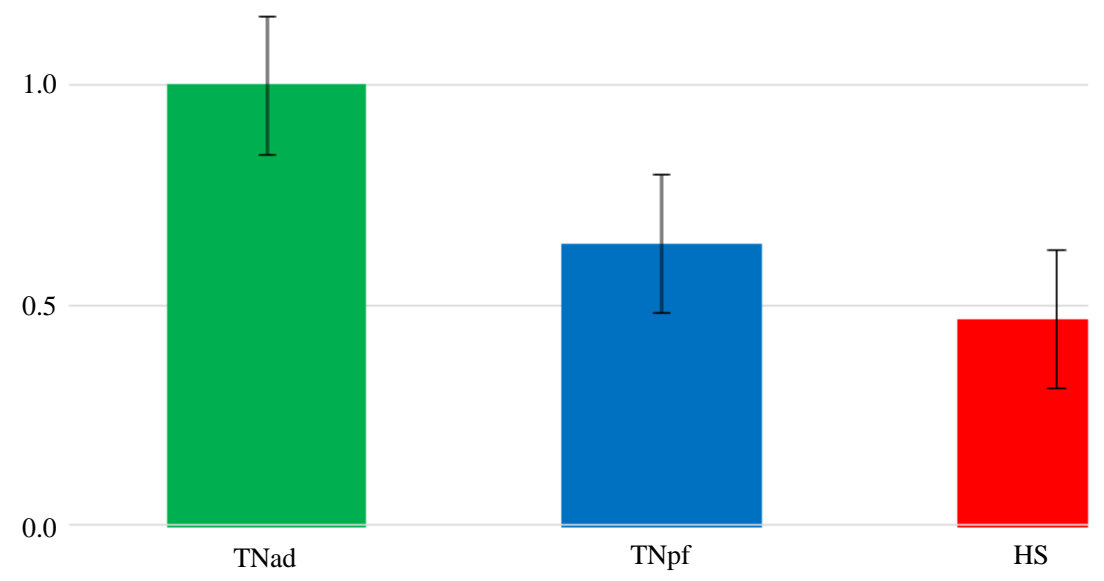

Fig. 4: Fold of increase-decrease on expression of mRNA for CYP3A analyzed in liver of pigs under thermoneutral ad libitum (TNad), thermoneutral pair fed (TNpf) or Heat Stress (HS) conditions

The mRNA expression of UCP3 in muscles (Fig. 3) was not affected in LD ( $\mathrm{p} \geq 0.855)$ and ST muscle $(\mathrm{p}=0.496)$ by the exposure of pigs to high ambient temperature at similar feed intake (HS vs. TNpf). Similarly, there was no effect of the feed intake level on the UCP3 mRNA expression in $\mathrm{LD}(\mathrm{p}=0.880)$ and $\mathrm{ST}(\mathrm{p}=0.648)$ muscles of pigs housed under TN conditions (TNad vs. TNpf). Moreover, the UCP3 expression in the LD ( $\mathrm{p}=0.738$ ) and $\mathrm{ST}(\mathrm{p}=0.818)$ muscles of HS pigs did not differ from that of TN pigs fed ad libitum (HS vs. TNad).

In liver, the mRNA expression of CYP3A (Fig. 4) was not affected by the exposure of pigs to high ambient temperature at similar feed intake (HS vs. TNpf; $\mathrm{p}=0.574$ ), or by the feed intake level of pigs housed under TN conditions (TNad vs. TNpf; $\mathrm{p}=0.411$ ). The expression of CYP3A in HS pigs did not differ from that of TN pigs fed ad libitum. In this study, we were no able to detect the expression of UCP3 in liver, or CYP3A in the LD or the ST muscles.

\section{Discussion}

The expression of HSP70, UCP3 and P450 in muscles and liver of pigs exposed to natural HS or TN conditions and different feed intake is part of a large data set obtained in the present experiment. Performance, mRNA expression for amino acid transporters and serum amino acids are published already (Morales et al., 2016).

The thermo-neutral zone for nursery-growing pigs is around $24^{\circ} \mathrm{C}$ (Huynh et al., 2005; Straw et al., 2006); at this temperature pigs can maintain normal physiological constants and show optimal growth performance. In the present experiment, housing temperature of $\mathrm{TNad}$ and TNpf pigs was around $26^{\circ} \mathrm{C}$, which is close to thermo- neutral zone. In contrast, HS pigs were exposed to an average AT of $33^{\circ} \mathrm{C}$, about $7^{\circ} \mathrm{C}$ above $\mathrm{TN}$ zone; moreover, HS pigs were exposed to AT as high as $37.2^{\circ} \mathrm{C}\left(11.2^{\circ} \mathrm{C}\right.$ above $\mathrm{TN}$ zone $)$. Thus, pigs housed in the HS room were exposed to HS conditions all the time. In addition, as previously reported (Cervantes et al., 2016; Cervantes et al., 2018), pigs exposed to HS conditions similar to those of the present experiment, reduced their feed intake, had increased BT, breath rate and lethargic state mainly during the afternoon when the highest temperature was recorded. These productive and physiological parameters alterations confirm that HS pigs were exposed to HS conditions.

The exposure of pigs to high AT increases their BT (Renaudeau et al., 2010; Pearce et al., 2013; Cervantes et al., 2018). According to Flanagan et al. (1995) hyperthermia results in a tissue-specific accumulation of HSP72, mostly in internal organs like liver. Heat shock proteins assist in the assembly, repair and refolding of damaged proteins under normal and stress conditions such as hyperthermia, energy depletion and increased ROS, among others (Kregel, 2002). Thus, an increase in HSP is a signal of cellular response to cope with those stressful conditions (Lanneau et al., 2010). Several reports show increased HSP70 expression in blood cells of cattle (Kumar et al., 2007; Gaughan et al., 2013; Bharati et al., 2017) and goats (Dangi et al., 2015) under chronic HS.

In the present study, the expression of HSP70 in liver of pigs after $21 \mathrm{~d}$ of exposure to HS increased 4-fold compared to TNad. This increased HSP70 expression in liver coincides with the 5-fold increase in HSP70 expression in liver and brain of HS tolerant goats during 
the peak of a HS period, compared to HS susceptible goats reported by Rout et al. (2016). Also Nagayach et al. (2017) observed an increase in HSP70 expression in liver and heart of goats during the summer. In agreement, we recently demonstrated that chronic HS increases the expression of HSP90 in liver, LD and duodenum of pigs (Morales et al., 2014; Cervantes et al., 2016). However, in the present study there was no effect of HS or feed intake on the expression of HSP70 in LD and ST muscles. Flanagan et al. (1995) reported that hyperthermia did not affect the accumulation of HSP72 in the peripheral tissues like muscles of the limbs. Although Pearce et al. (2013) observed an increase in the HSP70 expression in the LD muscle of pigs at d1 of HS exposure, it decreased at $\mathrm{d} 3$ and $\mathrm{d} 7$. This response indicates that the increased HSP70 expression in muscle may occur during a short period of time, thus animals may start to acclimate to chronic HS conditions (Gaughan et al., 2013). Other studies with pigs (Morales et al., 2014), cattle (Bharati et al., 2017), goats (Dangi et al., 2015) and mice (Sareh et al., 2011) showed a reduction in HSP70 expression after chronic or repeated exposure to heat stress. This partially explains the lack of effect on expression of HSP70 in both muscles analyzed in the present experiment. Larger expression of HSP70, according to Lacetera et al. (2006), can be associated to lower heat tolerance.

UCPs are a family of mitochondrial anion-carrier proteins that generate heat by dissipating the mitochondrial proton gradient, uncoupling respiration from ATP synthesis; this represents an important mechanism for generating heat in animals at rest (Palmieri, 1994; Dridi et al., 2004). UCP2 and UCP3 have been detected in muscles of pigs (Damon et al., 2000). UCP3 is expressed predominantly in skeletal muscle, heart and brown adipose tissue (Echtay, 2007; Ramsay and Richards, 2007) but not in liver (Schrauwen, 2002). Accordingly, in the present experiment, we detected the expression of UCP3 only in LD and ST muscles, but it was not detected in the liver of pigs. The action mechanism of UCP3 involves the transport of fatty acid anions (or peroxides) resulting from fatty acid oxidation into the mitochondrial matrix. Thus it appears that UCP3 protects mitochondria against oxidative damage by preventing the accumulation of oxidative species or ROS (Echtay, 2007; Cioffi et al., 2009; Busiello et al., 2015). Mitochondrial oxidative damage occurs by accumulation of protons in the intermembrane space and increased ROS emission from the electron transfer chain (Korshunov et al., 1997), whereas UCP3 uncouples the respiratory chain reducing the accumulation of ROS.

The expression of UCP3 is modified under stress conditions such as hyperoxia (Flandin et al., 2005), fasting (Cioffi et al., 2009; Busiello et al., 2015) and even under reduced protein intake (Ramsay and
Mitchell, 2008) because of its activity in fatty acid oxidation. Hence UCP3 could have an important role under HS conditions, when reduced feed intake and high mitochondrial production of ROS is usually observed (Baumgard and Rhoads, 2013; Slimen et al., 2015). Increased ROS production has been reported in several HS animals (Huang et al., 2015; Kikusato et al., 2016; Banh et al., 2016). Reduced expression of avUCP in muscule after acute HS exposition of chickens (Kikusato et al., 2016) and heat acclimation of myocytes (Salgado et al., 2017) has been reported. Mujahid et al. (2007) observed that $18 \mathrm{~h}$ of heat stress $\left(34^{\circ} \mathrm{C}\right)$ stimulated the superoxide production in mitochondria, probably by down-regulation of avUCP in muscle tissue. These authors hypothesized that appropriate UCP expression could help to a better adaptation to HS. The expression of UCP3 in muscle increased after the chronic exposure of pigs to HS in response to, apparently, the increased mitochondrial ROS production resulting from the exposure to heat (Katsumata et al., 2004). In the present experiment, however, neither HS nor feed intake affected the expression of UCP3, probably because pigs became acclimated after being exposed to to high AT during 21 d. Further studies are necessary in order to achieve a better understanding of the activity and function of these proteins.

The cytochrome enzymes CYPs are heme proteins located in the membrane of mitochondria and endoplasmic reticulum of several tissues including liver that participate in the detoxification process of compounds such as drugs (Rasmussen and Zamaratskaia, 2014). CYP3A is the most important and most studied mammalian heme protein (Sevrioukova and Poulos, 2013; Shang et al., 2013). Stress is a critical player in the regulation of most CYPs that could modify their activity and gene expression (Daskalopoulos et al., 2012). Decreased activity in rats (Damanhouri, 2002) and liver expression of this enzyme in mid-lactation of dairy cows due to the HS exposure (McCracken et al., 2015) were reported. Acute exposure of mouse to $40-42^{\circ} \mathrm{C}$ increased the expression of CYP3A in liver and promoted hepatocyte proliferation, but the exposure to $44-46^{\circ} \mathrm{C}$ inhibited proliferation and promoted apoptosis of hepatocytes (Li et al., 2012). Altered electron transport by cytochrome $\mathrm{P} 450$ in mammary epithelial cell culture exposed to $42^{\circ} \mathrm{C}$ during $1 \mathrm{~h}$ was also reported (Kapila et al., 2016). In the present experiment, the expression of CYP3A was detected only in liver, which is in agreement with other authors (Shang et al., 2013; Nielsen et al., 2017). However, the lack of effect of chronic HS on the expression of CYP3A may support the hypothesis that these pigs were acclimated to $\mathrm{HS}$ after the 21 exposure to high AT (Horowitz, 2001; Renaudeau et al., 2010; Yu et al., 2010). In general, it is 
likely that the cells and its cytochromes became adapted to HS, reducing the damages caused by the environmental conditions and explain the lack of effect of HS in CYP3A and UCP3 expression.

\section{Conclusion}

After a long exposure to HS, pigs increased their expression of the cytosolic protein HSP70 in liver, probably in order to maintain their proteins integrity. But the expression of mitochondrial proteins UCP3 and CYP3A in liver and muscles were unaffected by HS or feed intake. These results suggest that HS pigs became acclimated to HS after the exposure to high AT for $21 \mathrm{~d}$. Nevertheless, factors other than mitochondrial ROS production, increased BT and lower feed intake appear to be responsible for the poorer performance observed in pigs acclimated to HS.

\section{Acknowledgement}

This research was funded by National Science and Technology Council of México (CONACYT CB: 2012 project no. 00181348 and $\mathrm{CB}: 2016$ project no. 00287052). Authors also thank to CONACYT for providing scholarships to Montesinos-Cruz Verónica.

\section{Author's contribution}

V. Montesinos-Cruz: Carried out field and laboratory work, analyzed and interpreted the data for the manuscript, wrote a pre-manuscript.

M. Cota: Collaborated in fieldwork and participated in discussion of results.

L. Buenabad: Collaborated in laboratory work and data analysis.

M. Cervantes: Designed the experiment, advised field work and proofread the manuscript.

A. Morales: Designed and supervised the experiment and laboratory work, wrote the manuscript.

\section{Ethics}

The authors confirm that the present article is original and no ethical issues are concerned with it.

\section{Conflict of Interest}

The authors declare that they have no conflict of interest regarding the publication of this paper.

\section{References}

Bakau, B. and A.L. Horwich, 1998. The Hsp70 and Hsp60 chaperone machines. Cell, 92: 351-366. DOI: $10.1016 / \mathrm{S} 0092-8674(00) 80928-9$
Banh, S., L. Wiens, E. Sotiri and J.R. Treberg, 2016. Mitochondrial reactive oxygen species production by fish muscle mitochondria: Potential role in acute heat-induced oxidative stress. Comp. Biochem. Physiol. B Biochem. Mol. Biol., 191: 99-107.

DOI: 10.1016/j.cbpb.2015.10.001

Baumgard, L.H. and R.P.J.R. Rhoads, 2013. Effects of heat stress on postabsorptive metabolism and energetics. Ann. Rev. Anim. Biosci., 1: 311-337. DOI: 10.1146/annurev-animal-031412-103644.

Bernabucci, U., N. Lacetera, L.H. Baumgard, R.P. Rhoads and B. Ronchi et al., 2010. Metabolic and hormonal acclimation to heat stress in domesticated ruminants. Animal, 4: 1167-1183. DOI: $10.1017 / \mathrm{S} 175173111000090 \mathrm{X}$

Bharati, J., S.S. Dangi, V.S. Chouhan, S.R. Mishra and M.K. Bharti et al., 2017. Expression dynamics of HSP70 during chronic heat stress in Tharparkar cattle. Int. J. Biometeorol., 61: 1017-1027. DOI: $10.1007 / \mathrm{s} 00484-016-1281-1$

Busiello, R.A., S. Savarese and A. Lombardi, 2015. Mitochondrial uncoupling proteins and energy metabolism. Front Physiol., 6: 36. DOI: 10.3389/fphys.2015.00036

Cervantes, M., D. Antoine, J.A. Valle, N. Vásquez and R.L. Camacho et al., 2018. Effect of feed intake level on the body temperature of pigs exposed to heat stress conditions. J. Therm. Biol., 76: 1-7. DOI: $10.1016 /$ j.jtherbio.2018.06.010

Cervantes, M., M. Cota, N. Arce, G. Castillo and E. Avelar et al., 2016. Effect of heat stress on performance and expression of selected amino acid and glucose transporters, HSP90, leptin and ghrelin in gorwing pigs. J. Therm. Biol., 59: 69-76.

DOI: $10.1016 /$ j.jtherbio.2016.04.014

Cioffi, F., R. Senese, P. De Lange, F. Goglia and A. Lanni et al., 2009 Uncoupling proteins: A complex journey to function discovery. Biofactors, 35: 417-28. DOI: $10.1002 /$ biof.54.

Damanhouri, Z.A., 2002. The effect of heat stress on the induced hepatic drug metabolizing system in rats. Eur. J. Drug Metab. Pharmacokinet., 27: 69-73. DOI: $10.1007 /$ BF03190418

Damon, M., A. Vincent, A. Lombardi and P. Herpin, 2000. First evidence of uncoupling protein-2 (UCP2) and -3 (UCP-3) gene expression in piglet skeletal muscle and adipose tissue. Gene, 246: 133-41. DOI: 10.1016/S0378-1119(00)00061-5

Dangi, S.S., M. Gupta, S.K. Dangi, V.S. Chouhan and V.P. Maurya et al., 2015. Expression of HSPs: An adaptive mechanism during long-term heat stress in goats (Capra hircus). Int. J. Biometeorol., 59: 1095-1106. DOI: 10.1007/s00484-014-0922-5 
Daskalopoulos, E.P., F. Malliou, G. Rentesi, M. Marselos and M.A. Lang et al., 2012. Stress is a critical player in CYP3A, CYP2C and CYP2D regulation: role of adrenergic receptor signaling pathways. Am. J. Physiol. Endocrinol. Metab., 303: E40-54. DOI: 10.1152/ajpendo.00545.2011

Dridi, S., O. Onagbesan, Q. Swennen, J. Buyse and E. Decuypere et al., 2004. Gene expression, tissue distribution and potential physiological role of uncoupling protein in avian species. Comp. Biochem. Physiol., 139: 273-283.

DOI: 10.1016/j.cbpb.2004.09.010

Duester, G., 1996. Involvement of alcohol dehydrogenase, short chain dehydrogenase/reductase, aldehyde dehydrogenase and cytochrome $\mathrm{P} 450$ in the control of retinoid signaling by activation of retinoic acid synthesis. Biochem., 35: 12221-12227.

DOI: $10.1021 /$ bi961176

Echtay, K.S., 2007. Mitochondrial uncoupling proteins. What is their physiological role? Free Radic. Biol. Med., 43: 1351-1371.

DOI: 10.1016/j.freeradbiomed.2007.08.011

Flanagan, S.W., A.J. Ryan, C.V. Gisolfi and P.L. Moseley, 1995. Tissue-specific HSP70 response in animals undergoing heat stress. Am. J. Physiol., 268: R28-32. DOI: 10.1152/ajpregu.1995.268.1.R28

Flandin, P., Y. Donati, C. Barazzone-Argiroffo and P. Muzzin, 2005. Hyperoxia-mediated oxidative stress increases expression of UCP3 mRNA and protein in skeletal muscle. FEBS Lett., 579: 3411-5.

DOI: 10.1016/j.febslet.2005.04.084

García, H., A. Morales, A. Araiza, J.K. Htoo and M. Cervantes, 2015. Gene expression, serum amino acid levels and growth performance of pigs fed dietary leucine and lysine at different ratios. Genet. Mol. Res., 14: 1589-601.

DOI: 10.4238/2015.March.6.6

Gaughan, J.B., S.L. Bonner, I. Loxton and T.L. Mader, 2013. Effects of chronic heat stress on plasma concentration of secreted heat shock protein 70 in growing feedlot cattle. J. Anim. Sci., 91: 120-129. DOI: $10.2527 /$ jas.2012-5294

Horowitz, M., 2001. Heat acclimation: phenotypic plasticity and cues to the underlying molecular mechanisms. J. Therm. Biol., 26: 357-363. DOI: $10.1016 / \mathrm{S} 0306-4565(01) 00044-4$

Huang, C., H. Jiao, Z. Song, J. Zhao and X. Wang et al., 2015. Heat stress impairs mitochondria functions and induces oxidative injury in broiler chickens. J. Anim. Sci., 93: 2144-53. DOI: 10.2527/jas.2014-8739

Huynh, T.T., A.J. Aarnink, M.W. Verstegen, W.J. Gerrits and M.J. Heetkamp et al., 2005. Effects of increasing temperatures on physiological changes in pigs at different relative humidities. J. Anim. Sci., 83: 1385-1396. DOI: $10.2527 / 2005.8361385 x$
Kapila, N., A. Sharma, A. Kishore, M. Sodhi and P.K. Tripathi et al., 2016. Impact of heat stress on cellular and transcriptional adaptation of mammary epithelial cells in riverine buffalo (Bubalus Bubalis). PLoS One 11: e0157237.

DOI: 10.1371 /journal.pone.0157237

Katschinski, D.M., 2004. On heat and cells and proteins. News Physiol. Sci. 19: 11-15. DOI: $10.1152 /$ nips.01403.2002

Katsumata, M., M. Matsumoto, S. Kawakami and Y. Kaji, 2004. Effect of heat exposure on uncoupling protein-3 mRNA abundance in porcine skeletal muscle. J. Anim. Sci., 82: 3493-3499. DOI: $10.2527 / 2004.82123493 x$

Kikusato, M., K. Nakamura, Y. Mikami, A. Mujahid and M. Toyomizu, 2016. The suppressive effect of dietary coenzyme Q10 on mitochondrial reactive oxygen species production and oxidative stress in chickens exposed to heat stress. Anim. Sci. J., 87: 1244-1251. DOI: 10.1111/asj.12543

Korshunov, S.S., V.P. Skulachev and A.A. Starkov, 1997. High protonic potential actuates a mechanism of production of reactive oxygen species in mitochondria. FEBS Lett., 416: 15-18.

DOI: 10.1016/S0014-5793(97)01159-9

Kregel, K.C., 2002. Heat shock proteins: modifying factors in physiological stress responses and acquired thermotolerance. J. Appl. Physiol., 92: 2177-2186.

DOI: 10.1152/japplphysiol.01267.2001

Kumar, A., P. Kumar and S.V. Singh, 2007. Oxidative stress markers profile in erythrocytes of natural and heat exposed cattle and buffalos. Indian J. Dairy. Sci., 60: 114-118

Lacetera, N., U. Bernabucci, D. Scalia, L. Basiricò and P. Morera et al., 2006. Heat stress elicits different responses in peripheral blood mononuclear cells from Brown Swiss and Holstein cows. J. Dairy. Sci., 89: 4606-12.

DOI: $10.3168 /$ jds.S0022-0302(06)72510-3

Lanneau, D., G. Wettstein, P. Bonniaud and C. Garrido, 2010. Heat Shock Proteins: Cell Protection through Protein Triage. Scientific World J., 10: 1543-1552. DOI: $10.1100 /$ tsw.2010.152

Li, S.Q., R.F. Li, S.M. Xi, S. Hu and Z.Q. Jia et al., 2012. Systematical analysis of impacts of heat stress on the proliferation, apoptosis and metabolism of mouse hepatocyte. J. Physiol. Sci., 62: 29-43. DOI: $10.1007 / \mathrm{s} 12576-011-0183-6$

Livak, K.J. and T.D. Schmittgen, 2001. Analysis of relative gene expression data using real-time quantitative PCR and the 22DDCT method. Methods, 25: 402-408.

DOI: $10.1006 /$ meth.2001.1262 
McCracken, V.L., G. Xie, S.E. Deaver, L.H. Baumgard and R.P. Rhoads et al., 2015. Short communication: Hepatic progesteronemetabolizing enzyme cytochrome P450 2C and 3A in lactating cows during thermoneutral and heat stress conditions. J. Dairy Sci., 98: 3152-7. DOI: $10.3168 /$ jds.2014-8826

Méndez, V., E. Avelar, A. Morales, M. Cervantes and A. Araiza et al., 2011. A rapid protocol for purification of total RNA for tissues collected from pigs at a slaughterhouse. Genet. Mol. Res., 10: 3251-5.

DOI: 10.4238/2011.December.22.3

Mookerjee, S.A., A.S. Divakaruni, M. Jastroch and M.D. Brand, 2010. Mitochondrial uncoupling and lifespan. Mech. Ageing Dev., 131: 463-472.

DOI: $10.1016 / \mathrm{j} . \mathrm{mad} .2010 .03 .010$

Morales, A., F. Grageola, H. Garcia, N. Arce and B. Araiza et al., 2014. Performance, serum amino acid concentrations and expression of selected genes in pair-fed growing pigs exposed to high ambient temperatures. J. Anim. Physiol. Anim. Nutr., 98: 928-935. DOI: 10.1111/jpn.12161

Morales, A., L. Hernández, L. Buenabad, E. Avelar and H. Bernal et al., 2016. Effect of heat stress on the endogenous intestinal loss of amino acids in growing pigs. J. Anim. Sci., 94: 165-172. DOI: $10.2527 /$ jas2015-9393

Mujahid, A., Y. Akiba and M. Toyomizu, 2007. Acute Heat Stress Induces Oxidative Stress and Decreases Adaptation in Young White Leghorn Cockerels by Downregulation of Avian Uncoupling Protein. Poult. Sci., 86: 364-371. DOI: $10.1093 / \mathrm{ps} / 86.2 .364$

Nagayach, R., U.D. Gupta and A. Prakash, 2017. Expression profiling of hsp70 gene during different seasons in goats (Capra hircus) under sub-tropical humid climatic conditions. Small Rumin. Res., 147: 41-47.

DOI: $10.1016 /$ j.smallrumres.2016.11.016

Nielsen, S.D., Y. Bauhaus, G. Zamaratskaia, M.A. Junqueira and K. Blaabjerg et al., 2017. Constitutive expression and activity of cytochrome P450 in conventional pigs. Res. Vet. Sci., 111: 75-80. DOI: 10.1016/j.rvsc.2016.12.003

NOM-062-ZOO-1999, 2001. In: Ochoa, M.L.I. (Ed.), Especificaciones técnicas para la producción, cuidado y uso de los animales de laboratorio. Diario Oficial de la Federación. México (DF), México.

NRC, 2012. Nutrient Requirements of Swine. 11th Edn., National Academy Press, Washington, DC.

Palmieri, F., 1994. Mitochondrial carrier proteins. FEBS Lett., 346: 48-56.

DOI: $10.1016 / 0014-5793(94) 00329-7$
Pearce, S.C., N.K. Gabler, J.W. Ross, J. Escobar and J.F. Patience et al., 2013. The effects of heat stress and plane of nutrition on metabolism in growing pigs. J. Anim. Sci., 91: 2108-18. DOI: $10.2527 /$ jas.2012-5738

Ramsay, T.G. and A.D. Mitchell, 2008. Impact of dietary protein content on uncoupling protein mRNA abundance in swine. Comp. Biochem. Physiol., B 149: 562-57.

DOI: $10.1016 /$ j.cbpb.2007.11.007

Ramsay, T.G. and M.P. Richards, 2007. $\beta$-Adrenergic regulation of uncoupling protein expression in swine. Comp. Biochem. Physiol., A 147: 395-403. DOI: 10.1016/j.cbpa.2007.01.007

Rasmussen, M.K. and G. Zamaratskaia, 2014. Regulation of Porcine Hepatic Cytochrome P450 Implication for Boar Taint. Comput. Struct Biotechnol. J., 11: 106-112. DOI: $10.1016 /$ j.csbj.2014.09.003

Renaudeau, D., C. Anais, L. Tel and J.L. Gourdine, 2010. Effect of temperature on thermal acclimation in growing pigs estimated using a nonlinear function. J. Anim. Sci., 88: 3715-3724. DOI: $10.2527 /$ jas.2009-2169

Rhoads, R.P., L.H. Baumgard and J.K. Suagee, 2013. Metabolic priorities during heat stress with an emphasis on skeletal muscle. J. Anim. Sci., 91: 2492-2503. DOI: $10.2527 /$ jas2012-6120

Rout, PK., R. Kaushik and N. Ramachandran, 2016. Differential expression pattern of heat shock protein 70 gene in tissues and heat stress phenotypes in goats during peak heat stress period. Cell Stress Chaperones, 21: 645-651.

DOI: $10.1007 / \mathrm{s} 12192-016-0689-1$

Salgado, R.M., A.C. Sheard, R.A. Vaughan, D.L. Parker and S.M. Schneider et al., 2017. Mitochondrial efficiency and exercise economy following heat stress: A potential role of uncoupling protein 3 . Physiol. Rep., 5: e13054-e13054.

DOI: $10.14814 /$ phy2.13054

Sambrook, J. and D.W. Russell, 2001. Molecular Cloning: A Laboratory Manual, 3rd Edn., Cold Spring Harbor Laboratory Press, New York.

Sareh, H., M.E. Tulapurkar, N.G. Shah, I.S. Singh and J.D. Hasday, 2011. Response of mice to continuous 5-day passive hyperthermia resembles human heat acclimation. Cell Stress Chaperones, 16: 297-307. DOI: $10.1007 / \mathrm{s} 12192-010-0240-8$

Schrauwen, P., 2002. Skeletal muscle uncoupling protein 3 (UCP3): Mitochondrial uncoupling protein in search of a function. Curr. Opin. Clin. Nutr. Metab. Care, 5: 265-70

Sevrioukova, I.F. and T.L. Poulos, 2013. Understanding the mechanism of cytochrome P450 3A4: Recent advances and remaining problems. Dalton Trans., 42: 3116-26. DOI: $10.1039 / \mathrm{c} 2 \mathrm{dt} 31833 \mathrm{~d}$ 
Shang, H., K. Guo, Y. Liu, J. Yang and H. Wei, 2013. Constitutive expression of CYP3A mRNA in Bama miniature pig tissues. Gene, 524: 261-267. DOI: $10.1016 /$ j.gene.2013.04.007

Slimen, I.B., T. Najar, A. Ghram and M. Abdrrabba, 2015. Heat stress effects on livestock: Molecular, cellular and metabolic aspects, a review. J. Anim. Physiol. Anim. Nutr., 100: 401-412.

DOI: $10.1111 /$ jpn.12379

Straw, B.E., J.J. Zimmerman, S.D. Allaire and D.J. Taylor, 2006. Diseases of Swine. 9th Edn., Blackwell Publishing. Oxford, UK.
Wilson, T.E. and C.G. Crandall, 2011. Effect of thermal stress on cardiac function. Exerc. Sport Sci. Rev., 39: 12-17.

DOI: 10.1097/JES.0b013e318201eed6

Yu, J., P. Yin, F. Liu, G. Cheng and K. Guo et al., 2010. Effect of heat stress on the porcine small intestine: A morphological and gene expression study. Comp. Biochem. Physiol. A, 156: 119-128.

DOI: 10.1016/j.cbpa.2010.01.008 